\title{
Survey on Occurrence of Bacterial Diseases in Carp Culture Ponds of West Godavari, Andhra Pradesh
}

\author{
T. Suguna* \\ Fisheries Research Station, S.V. Veterinary University, West Godavari, \\ Andhra Pradesh - 534 199, India \\ *Corresponding author
}

\begin{tabular}{l} 
K e y w o r d s \\
Carps, Causes of \\
occurrence, \\
Controlling \\
measures, Diseases, \\
Etiological agents \\
\hline Article Info \\
Accepted: \\
20 September 2020 \\
Available Online: \\
10 October 2020
\end{tabular}

\section{A B S T R A C T}

Aquaculture is one of the fastest growing food producing sector in the world. In India over the last three decades, aquaculture has developed significantly, earning considerable amount of foreign exchange, besides providing employment. Freshwater aquaculture has been the main stay of Indian aquaculture, in terms of total quantity as well as its share in the domestic fish basket. India is called as carp country as carp production contributes in bulk (over 82\%). In Andhra Pradesh fish and shrimp culture is income generating profession. The district West Godavari of Andhra Pradesh, is specifically the fish bowl of India, generating an amount of Rs. 15.00 crores annually. Semi intensive culture practice is common, in an area of more than 2.0 lakh acres. In course of expansion and intensification of this semi extensive culture practice of the Indian major carps, over the last three decades, many economically important problems have been identified which are threatening the sustainability of the culture system. Occurrence of diseases is one of such factor affecting the socio-economic status of aqua farmers. To overcome this, an intensive surveillance was carried to document the prevalence of various diseases, season of occurrence, disease diagnosis, etiological agents, mortality rates and controlling measures, so that the severe risk for sustainability and huge economic loss can be arrested. The frequency in occurrence of septicaemia and bacterial gill diseases are recorded. The incidence of diseases and mortality rate are high in winter season.

\section{Introduction}

Aquaculture in India is a progressively growing food production system which fulfils adequate requirement of protein sources to the society globally. India is the second largest fish producing country (DADF; 2016). The sector has shown significant growth from traditional culture practices to commercial methods of culture, enhancing fish production from a mere 7.5 lakh tonne in 1950-51 to 107.95 lakhs tonne during 2015-16, earning crores of rupees through export of fish to different countries (Mishra et al., 2017). In Andhra Pradesh, this aqua sector has benchmarked from a domestic activity to an enterprise, where in the indigenous major carps: Catla (Catla catla), rohu (Labeo rohita), mrigal (Cirrhinus mrigal), exotic carps like common carp (Cyprinus carpio) 
grass carp (Ctenopharyngodon idella), silver carp (Hypophthalmicthys molitrix) along with air breathing fishes, Clarias batrachus, Heteropneuestes fossils, Pangasius sps. are being widely cultured accounting for bulk of freshwater aquaculture production. In the last few years, the exotic catfish Pangasianodon hypophthalmus and pacu Piaractus branchypomus culure is also increasing. Tilapia and Pangasius are, also offer opportunities for cage culture. The focus on the production of genetically improved tilapia for market as cheep source of proteins is also enhancing (Jelte de Jong, 2017). In Andhra Pradesh, fish and shrimp culture is predominant income generating profession. Further, this state leads first in position in aquaculture production of the nation. In the state, it is estimated that more than $80 \%$ of the fish production arise from the fish bowl area i.e. Krishna, East Godavari and West Godavari districts. Of these districts, West Godavari plays a lead role especially in freshwater fish production. Production of IMC i.e. Catla, Rohu and Mrigala contribute $80-85 \%$ of total fish production. With a culture area of 2.0 lakh acres the aqua production of the district is 10,51,754 tones (17-18), 10.00 lakh metric tons (18-19) and 11.0 lakh metric tons (19-20) respectively.

In spite of the unprecedented development of semi intensive culture of Indian major carps, many economically important problems has been identified, that are threatening the sustainability of the culture system. The expansion and intensification of aqua farming practices lead to health problems in culturing fishes, thereby reducing the production rate. The degraded environmental parameters, also influenced the occurrence of infectious diseases. Disease is one of the major constraints to aquaculture and limiting factor for economic and socio-economic development in India and also as in many other countries of the world (Begum et al.,
2013, Mohan et al., 2002; Sahoo, 2013). Some disease has caused serious damage, not only the livelihood of fish farmers, but also to the future development of the industry. Many diseases affecting present day aquaculture is resultant of intensification of culture practices (Walker and Winton, 2010) without the basic perception of intricate balance between host, pathogen and environment (Bondad Reantaso et al., 2005, Subasingha et al., 2001). In Andhra Pradesh the increase in aqua production particularly in expansion into intensive and semi intensive methods of production has been coupled by increase in fish and shell fish resulting from high stocking densities and stress condition that favours the occurrence and spread of infectious diseases (Das and Mishra, 2014). 1) As the scope for horizontal expansion is limited, the current trend in aquaculture development is focused towards intensification of the culture practices. The vertical expansion of fish culture with diversified species and high stocking density has resulted in more frequent occurrence of bacterial, parasitic and viral pathogens, often leading to higher morbidity or mass mortalities and lowered production. 2) The frequent occurrence of diseases and epizootics are considered to be major bottlenecks for increasing production. The diseases are mostly bacterial and parasitic origin. The diseases account for 10-5\% towards the production cost (Sahoo et al., 2017). The occurrence of disease is a result of the complex interaction between the host, pathogen and the environment (Snieszko, 1974). In aquatic systems, disease management is a difficult proposition due to the unique ecosystem, where the pathogen is always looking for an opportunity when the health status of the host is comprised (Vijayan and Sanil, 2012). In many cases, diseases out breaks are closely related to environmental deterioration, leading to stress to the cultured animals. Different stress factors such as non 
optimal water quality, higher microbial load, poor nutritional status, high stocking density will trigger the chances of infection by opportunistic pathogens in aquatic environment (Mishra et al., 2015). Most bacterial, parasitic and fungal pathogens are not strictly parasitic micro organisms. These pathogens have a high adaptability to environmental changes. If the conditions for parasitism are unsuitable, saprophytic relationship will develop. Environmental stress factors and organic loadings are identified as causes for further infections (Shaovi Li, 1989). Lack of knowledge of fish health management and skill to prevent and control disease outbreak is leading to huge economic loss (Bagum et al., 2013). This study throws light on various diseases, frequency and seasonal variation in occurrence, etiological agents, mortality rate and also controlling measures.

\section{Materials and Methods}

The samples of fish (1073) and water (2118) were collected fortnightly, from various ponds of different villages of 242 aqua farmers from 2019 April to 2020 March in West Godavari. The water sample were analysed for various physical and chemical factors by following standard procedures. The fish are disease diagnosed, morphologically and microscopically in our Aquatic Animal Health Referral Laboratory, Fisheries Research Station, Sri Venkateswara Veterinary University, Undi, Bhimavaram, West Godavari district. Anamnesis and parasitological diagnosis were performed and recorded.

The gills and other internal organs were excised and maintained into petri dish with $0.65 \%$ saline solution. The slime mount of gill were studied microscopically for diagnosis of internal parasites. A scraping of body surface mucus in skull - tail direction was performed to search for parasites microscopically. The severity of disease is recorded by observation of internal organs.

\section{Results and Discussion}

Carp culture area of 4964 acres was surveyed in West Godavari district, covering 242 aqua farmers from twenty villages (Table. 1). The size of the culture ponds ranged from 5-25 acres. The incidence of 2078 cases of bacterial diseases and their receptive etiological agents were recorded (Table 2 and $3)$. In bacterial diseases the occurrence of Bacterial Gill Disease (BGD) is higher (1170 cases, 56.3\%) than that of septicaemia (908 cases, 43.7\%) (Table 3) (Fig. 1, 2a, 2b). Comparatively winter season is the peak period of bacterial disease occurrence (Fig. $3)$.

Bacterial fish diseases are very common and most difficult health problems to deal. They are generally saprophytic in nature but can become pathogenic when fishes are physiologically unbalanced, deficient in nutrition, over stocking and poor water quality. The microorganisms are essentially opportunistic pathogens which invade the tissues of a fish host and become susceptible to infection by the stress factors (Ahmed, K., Kumar W.A.G. 2005).

The Aeromonad septicaemia is caused by the etiological agent, Aeromonas hydrophilla. Its presence is there more or less throughout the year in Catla and rohu (Table 2, Fig. 2). The bacterial gill disease is also caused by another species of bacteria i.e. Flovobacterium branchiophyllum (Table 2, Fig. 3). Even though infects both catla and rohu but its occurrence is more severe in rohu which leads to heavy mortality. Comparatively winter season is the peck period of bacterial disease occurrence (Fig. 4). 
In general there are four types of bacterial infections 1) fin rot - usually resulting from the environmental stress, 2) bacterial body ulcers - open, shallow to deep, lesions on the fishes body (FAO 2014), 3) bacterial gill disease - in which the gills are the primary targets (FAO 2014). The details of common bacterial diseases are reported in aquaculture are presented in table 2,4) Another important bacterial disease often confused with red disease in carp culture is motile aeromonas septicaemia in which bacteria invade and cause damage to internal organs. This is probably the most common bacterial disease causing severe production loss to freshwater fish culture. The disease has been associated with several number of the genus aeromonas, including A. Hydrophila, A. Sobria, A. Caviae, A. Schuberti and A. Veronii. The clinical signs of motile Aeromonas septicaemia include high mortality often with superficial to deep skin lesions (Fig. 2) and sometimes sudden death with or without any clinical symptoms. Skin lesions are often noticed at the base of the fins with variously sized areas of haemorrhage and necrosis. There are red areas on the body, skin ulcers, swollen body, abdomen and eyes and musculature, hence often called as "red disease" (Fig. 2). These lesions may progress to reddish to grey ulcerations with necrosis of the underlying. If immediate action is not taken, the mortality rate often reaches to $100 \%$. The Flexibacter columnaris affects the skin or gills of fish (Fig. 3).

Bacterial diseases have been frequently encountered in eggs, fry and fingerlings of fish also causing heavy mortality. The bacterial diseases like motile aeromonads septicaemia caused by Aeromonas hydrophila, eswardsiellosis caused by Edwardsiella tarda, Pseudomonas septicaemia by Pseuudomonas fluorescens and Pseudomonas putrafaciens, flexibacteriosis by flexibacter columnar, vibriosis by Vibrio alginolyticus and $V$. parahaemolyticus bacterial gill disease, streptococeel septicaemia, mycobacteriosis disease and enteric septicaemia, are often being reported in carp culture in India (Mukharjee, 2002, Mohanty et al., 2007)

Another significant observation in Indian Major Carp culture is the seasonal variation in occurrence and severity of fish diseases in carp culture (Fig. 4). The incidence of red disease or aeromoniasis are common during all reasons, whereas the incidences of black gill disease are more during winter periods and post rainy seasons (Fig. 4).

Table.1 Location of the surveyed carp culture ponds in West Godavari district, Andhra Pradesh

\begin{tabular}{|l|l|}
\hline Pedapulleru & Malvanithippa \\
\hline Eelampudi & M.M. Puram \\
\hline Fathepuram & Alapadu \\
\hline Dirsumarru & Tadinada \\
\hline Undi & Tummaguppa \\
\hline Ai. Bhimavaram & Sriparru \\
\hline Bondada lanka & Kalavapudi \\
\hline Pedakapavaram & Poola \\
\hline Akividu & Agadalalanka \\
\hline Siddapuram & Nidamarru \\
\hline
\end{tabular}


Table.2 Common diseases recorded from carp farming ponds.

\begin{tabular}{|c|c|c|c|}
\hline Sl. No. & Disease condition & Symptoms & Etiological agent \\
\hline \multicolumn{4}{|c|}{ A. Bacterial diseases: } \\
\hline 1. & Columnaris & $\begin{array}{l}\text { Haemorrhagic and ulcerative lesions on fins, } \\
\text { head, back }\end{array}$ & $\begin{array}{l}\text { Flexibacter } \\
\text { columnaris }\end{array}$ \\
\hline 2. & Tail rot and fin rot & $\begin{array}{l}\text { Erosions, discoloration and disintegration of } \\
\text { fins and tails. }\end{array}$ & A. hydrophilla etc. \\
\hline 3. & $\begin{array}{l}\text { Bacterial gill disease or gill } \\
\text { rot }\end{array}$ & $\begin{array}{l}\text { Gasping, lethargic, gills look discoloured with } \\
\text { trapped materials, secondary fungal infection. }\end{array}$ & $\begin{array}{l}\text { Flavobacterium } \quad M \\
\text { brachiophilum etc. }\end{array}$ \\
\hline 4. & Vibriosis & $\begin{array}{l}\text { Ulcerative abscesses in internal organs, } \\
\text { harmorrhagic ulcers on skin, fins and body. }\end{array}$ & $\begin{array}{l}\text { Vibrio } \\
\text { parahaemolyticus etc. }\end{array}$ \\
\hline 5. & Pseudomoniasis septicaemia & Haemorrhagic lesions on skin, fins, tail & Pseudomonas sps. \\
\hline
\end{tabular}

Table.3 The percentage of disease incidence of main bacterial diseases during April 19 to March 20

\begin{tabular}{|c|c|c|}
\hline SI. No. & \multicolumn{1}{|c|}{ Diseases } & \multicolumn{1}{c|}{ Cases } \\
\hline I. & Bacterial diseases & 2078 \\
\cline { 2 - 3 } & a. Motile aeromonad septicaemia & $908-43.7 \%$ \\
\hline b. Bacterial gill diseases & $1170-56.3 \%$ \\
\hline
\end{tabular}

Table.4 The percentage of mortality of fish in culture ponds (month wise)

\begin{tabular}{|l|l|}
\hline April 2019 & $\mathbf{6 . 2 6 \%}$ \\
\hline May 2019 & $4.78 \%$ \\
\hline June 2019 & $5.86 \%$ \\
\hline July 2019 & $5.62 \%$ \\
\hline August 2019 & $5.24 \%$ \\
\hline September 2019 & $7.56 \%$ \\
\hline October 2019 & $9.80 \%$ \\
\hline November 2019 & $10.30 \%$ \\
\hline December 2019 & $17.17 \%$ \\
\hline January 2020 & $13.23 \%$ \\
\hline February 2020 & 7.60 \\
\hline March 2020 & $12.39 \%$ \\
\hline
\end{tabular}

Table.5 Water temperature data (range) in ponds during April 19 to March 20

\begin{tabular}{|l|l|}
\hline pH & $\mathbf{7 . 5}-\mathbf{8 . 5}$ \\
\hline Salinity & $0-3.8 \%$ \\
\hline Dissolved oxygen $(\mathbf{m g} / \mathbf{l})$ & $2.8-4.8$ \\
\hline Total alkalinity $(\mathbf{m g} / \mathbf{l})$ & $120-450$ \\
\hline Total hardness $(\mathbf{m g} / \mathbf{l})$ & $100-500$ \\
\hline Total ammonia & $0.01-2.3$ \\
\hline
\end{tabular}




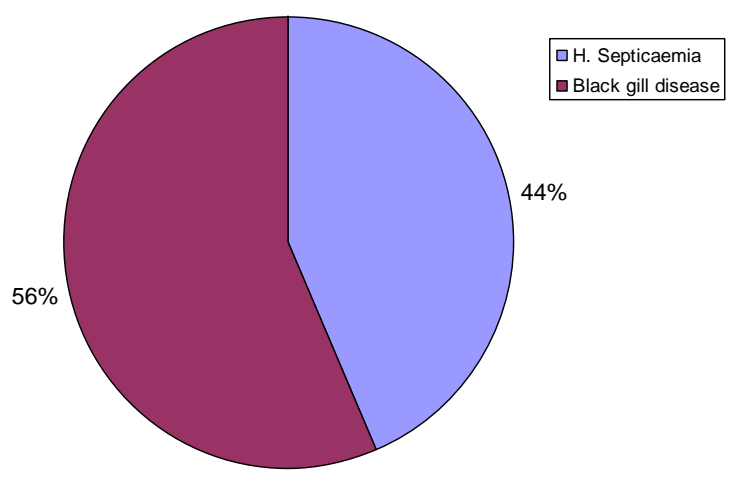

Fig.1 Incidence of main bacterial disease

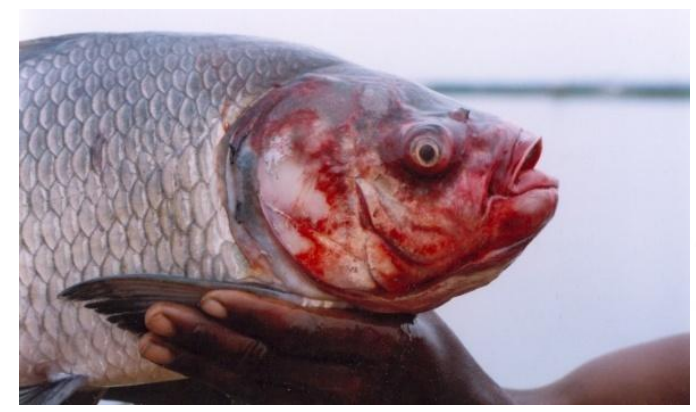

Fig.2 Motile aeromonad septicaemia

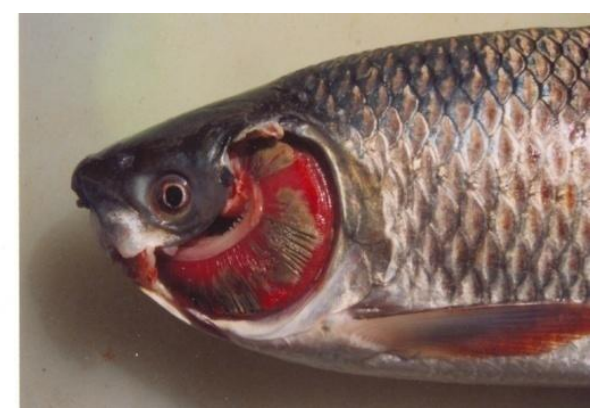

Fig.3 Bacterial gill disease

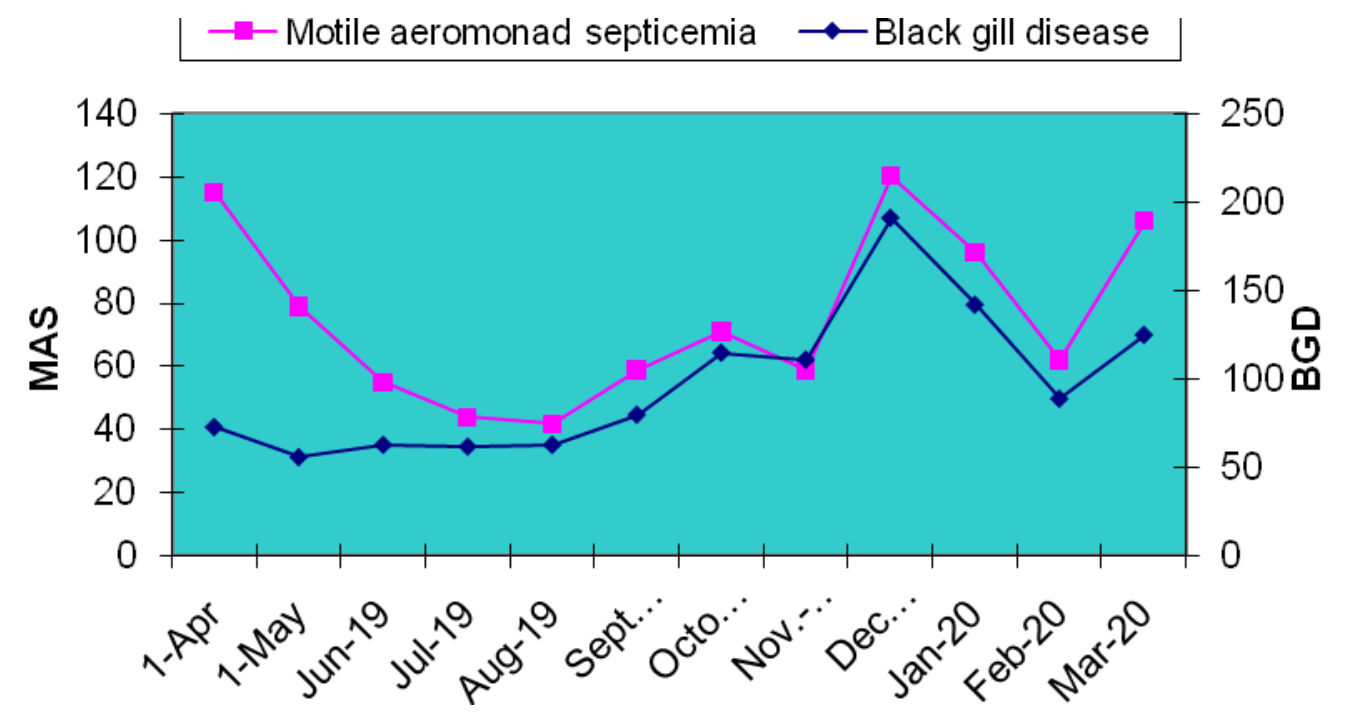

Fig.4 Incidence of bacterial diseases 
The mortality rate is also higher in winter season (Table 4). The water quality parameters of some culture ponds are maintained in optimum level (Table 5). In view of above, the farmers are advised to take due preventive and control measures during post rain and winter seasons, in grow out culture systems.

Conclusions of the study are as follows:

The transformation of Aquaculture activity from traditional to commercial scale, has led to drastic increase of production levels, simultaneously earning crores of rupees through export. Due to lucarativeness, the farmers are proceeding from semi intensive to intensive culture practices along with heavy inputs. The heavy inputs of feed, fertilizers, chemicals and probiotics bring in lot of changes in water quality parameters, resulting in negative effects, which lead to stress and finally occurrence of diseases.

In the survey 2078 cases of bacterial diseases are observed. In bacterial diseases, $43.7 \%$ of the motile aeromonad septicaemia and 56.3\% of bacterial gill diseases are being reported in carp culture in India. The aeromonas septicaemia is probably the most common bacterial disease causing severe production loss to freshwater fish culture (Mukharjee, 2002; Mohanty and Sahoo, 2007). Irrespective of the season, this red disease including, "dropsy" is noticed throughout the calendar year. The higher levels of bacterial load are noticed in the culture ponds, where in water quality parameters are deteriorated. The development of suitable preventive and control measures, specific therapy for fish diseases assumes paramount significance, for the farmers to protect their crop against pathogens. The implementation of Better Management Practices (BMP) is most important, to prevent frequent occurrence of disease and production loss in aquaculture.
Further enhancement in knowledge about the disease process, host - pathogen and the environment interaction leading to disease occurrence, are very much essential (Subasingha, 2001). This needs immediate due attention by the farmers for attaining of higher yields. Farmers are now in practice of using various probiotic formulations, aqua drugs and chemicals, various antimicrobials, sanitizers, anti-parasitic drugs and even antibiotics in fish culture system, as preventive and control measures to protect the crops (Anon, 2017; Mishra et al., 2017; Anon et al., 2017). But in view of all these a good understanding of disease prevalence status, indigenous technologies for disease prevention and control, implementation of farm level best management practices in water quality parameters, feed, health are the key components, which must be given due attention for sustainable fisheries production in the region.

\section{Acknowledgement}

The author is highly thankful to the Director of Research, Sri Venkateswara Veterinary University for providing the necessary facilities for carrying out this work.

\section{References}

Ahmed, K., Kumar, W.A.G.: Handbook on Fish and Crustacean diseases in the SAARC region ( $1^{\text {st }}$ education $)$, SAARC Agricultural Information Centre, Bangladesh

(http://www.Worldcat.org./title/handbo ok-on-fish-and-crustacean-diseases in the saare region / OCIC / 191696787) (2005).

Anon: Cifax Fish Medicine, Agrawal Trading Company, Raipur, Chhattisgarh, India (https//:www.indiamart.com/proddetail/ cifax-fish-medicine 12936885597.html) (2017). 
Bagum N, monir M.S., Khan M.H.: Present status of fish diseases and economic due to incidence of disease in rural freshwater aquaculture of Bangladesh. J. Innov Dev. Strategy 7: 48-53 (2013).

Bondad - Reanrago M.G., Subasinghe R.P., Arthur, J.R., Ogawa, K., Chinabut S, et al., Disease and health management in Asian aquaculture. Vet Parasitol. 132:249-272 (2005).

Das B.K., Misha S.S.: Diseases in Freshwater Aquaculture, In: Training Manual on model training course on preventive health management practices in freshwater aquaculture. ICAR - Central Institute of Freshwater Aquaculture, Bhubaneswar, Odisha, India (2014).

Jelte, de Jong: Aquaculture in India, Rijksdienst Voor Ondernemend Nederland.

(https://www.rvo.nl.sites/default/files/2 017/04/aquauclture-in-india-report2017.pdf) (2017).

Mishra S.S., Dhiman M., Swari, P, Das, B.K.: Fish disease and health management issues in aquaculture ICAR - CIFA Training manual No. 18, Central Institute of Freshwater Aquaculture, Bhubaneswar, India (2015).

Mishra, S.S., Das, R., Das, B.K., Choudhary, P., Rathora, R. et al., Status of Aqua medicines, Drugs and Chemicals use in India. A survey report J. Aqua. Fisheries (2017).

Mohan C.V., Bhatta R.: Social and economic impacts of aquatic animal health problems on aquaculture in India In: Arthur J.R., Philips M.J, Subasinghe R.P., Reantago M.B., Mac Rae (eds), Primary aquatic animal health care in rural, small scale, aquaculture development. Food and Agriculture Organization of the United Nations, Rome, Italy (2002).

Mohanty, B.R., Sahoo, P.K.: Edwardsiellosis in fish a brief review. J. Biosci 32: 1331
- 1344 (2007).

Mukharjee, S.C.: Fish diseases in India, their causes and control measures - Winter school on recent advances in diagnosis and management of disease in maricutlure, $7^{\text {th }}$ to $27^{\text {th }}$ November 2002, course Manual, Central Marine Fisheries Research Institute, Cochin, India (2002).

Sahoo P.K., Mohanty, J., Garnayak, J.S.K., Mohnaty B.R., Kar Banya: Estimation of loss due to argulosis in carp culture ponds in India. Indian J. Fish. 60: 99102 (2013).

Sahoo, P.K., Pradhan, P.K., Sundaray, J.K., Lal, K.K., Swaminathan, T.R.: Present status of freshwater fish and shellfish diseases in India. In: Proceedings of International symposium on Aquatic Animal Health and Epidemiology for sustainable Asian Aquaculture. ICAR National Bureau of fish genetic resources (2017).

Shaovi, Li.: Main fish diseases and their control. In integrated Fish Farming in China (ed). NACA Technical Manual 7. A World Food Day Publication of the Network of Aquaculture Centres in Asia and the Pacific, Bangkok, Thailand (1989).

Snieszko, S.F.: The effects of environmental stress on the outbreaks of infectious disease of fish. Journal of Fish Biology 6: 197-208. (http://onlinelibrary.wiley. com/doi/10.1111/j.1095-8649. 1974.tb04537.X/abstract) (1974).

Subasinghe, R.P., Bondad - Reantago, M.G., Mc Gladdary S.E.: Aquaculture development, health and wealth In: Subasinghe R.P., Reantago MQB, Mc Gladdary S.E. (Eds). Aquaculture in the Third Millennium Technical proceedings of the conference on Aquaculture in the Third Millennium, Bangkok, Thailand Pg. No: 167-191 (2001). 
Vijayan, K.K., Sanil, N.K.: Health Management Strategies for profitable and sustainable aquaculture, with special reference to diagnostics. In: Swain, S.K., Swain, P., Pillai, B.R., Raghunath, M.R., Jayasankar, P. (eds). Lead papers on strategies for Aquaculture Development ICAR Central Institute of Freshwater
Aquaculture, Bhubaneswar, India (2012).

Walker, P.J., Winton, J.R.: Emerging viral disease of fish and shrimp. Vet Res. 41:51 (https://www.nebi.nlm.nih.gov/ pmc/articles/PMC2878170) (2010).

\section{How to cite this article:}

Suguna, T. 2020. Survey on Occurrence of Bacterial Diseases in Carp Culture Ponds of West Godavari, Andhra Pradesh. Int.J.Curr.Microbiol.App.Sci. 9(10): 2556-2564. doi: https://doi.org/10.20546/ijcmas.2020.910.307 